\title{
Articulos
}

\section{Genomic Biorepository of Coastal Marine Species in Estero Padre Ramos and Estero Real, Nicaragua}

\author{
Jorge A. Huete-Pérez*, Eduardo N. Mendoza-Ramirez** and Lucía \\ Páiz-Medina **
}

Recibido: noviembre 2012/ Aceptado: diciembre 2012

Nicaragua, located in southern Mesoamerica between the Caribbean Sea and the Pacific Ocean, has acted as a land bridge for flora and fauna migrating between North and South America during the last 3 million years. Because of Nicaragua's location and history, it is rich in terrestrial and aquatic biodiversity. To study this biodiversity and preserve it for the future, Nicaragua's Molecular Biology Center at the University of Central America (CBM-UCA) created the Genomic Biorepository Project. The Project collects and catalogs coastal marine biodiversity in the Estero Real and Padre Ramos estuaries, located in Nicaragua's northern Pacific region. The biorepository holds more than three thousand tissue and genomic specimens, comprising 1,049 samples (714 specimens from Estero Padre Ramos and 335 from Estero Real) belonging to 100 species and 54 families, genomic extracts in triplicates for every sample collected and environmental sandy sediments representing 60 different sites. Changes in the biological composition of the region were documented as compared to previous sampling. Of the 1,049 samples obtained from the two estuaries, 30 new residents were recorded in Estero Real, and 19 in Estero Padre

* Dr. Jorge A. Huete-Perez is director of the Molecular Biology Center at UCA and a research scientist at Ocean Genome Legacy, MA. ,USA. Correo electronic: jorgehuete@uca-cbm.org

** Molecular Biology Center, Universidad Centroamericana. Managua, Nicaragua

*** Molecular Biology Center, Universidad Centroamericana. Managua, Nicaragua 
Ramos. The Cytochrome Oxidase I (COI) gene was sequenced for a number of species, including 19 fish species, and published to public databases (BOLD SYSTEMS). The records contained in the genomic biorepository here described lay the foundation for the most complete marine biodiversity database in Nicaragua and is made available to national and international specialists, facilitating knowledge of Nicaraguan biodiversity

Keywords: Biorepository, DNA Barcode, Nicaraguan Biodiversity, Cytochrome Oxidase I (COI).

\section{Introduction}

Ocean ecosystems are experiencing accelerated loss of populations and species, with unknown future results. Marine biodiversity loss is increasingly deteriorating the ocean's capacity to provide food, maintain water quality and recover from disruptive events (Worm et al., 2006). Since the implementation of the Convention on Biodiversity (CBD), the international community has been striving to reduce the rate of biodiversity loss. Its goals, however, have not been met ${ }^{1}$. In the tropics, a variety of factors play a role in this process, including biological and evolutionary processes, as well as human activity and socio-economic factors.

Nicaragua is fortunate to include within its marine territory an ample portion of the Caribbean Sea, encompassing the largest barrier reef in the Americas, considered an exceptional 'hot-spot' of unparalleled mega-biodiversity, and home to a treasure of native and endemic species. Nonetheless, environmental degradation and persistent overfishing in the Caribbean, is contributing to the deterioration of these extraordinary barrier reefs. The huge increase in destructive fishing practices is damaging marine mammals and entire ecosystems.

There is a pressing need to record, preserve and study the disappearing biological diversity of the Caribbean before many of the existing species are lost forever. To help protect these neglected coastal marine environments, it is of critical importance that a baseline of the current status and trends of the region's species and ecosystems, with special attention toward those at risk. Within the Caribbean, the least studied environments and marine species are those along the coasts of the less developed Central American countries.

To address a number of these difficulties, Nicaragua's Molecular Biology Center at the University of Central America (CBM-UCA) has established a research program to study and protect the country's marine biodiversity. The program incorporates ongoing and successful international cooperation between the Molecular Biology Center of the University of Central America (MBC/UCA) in Managua, Nicaragua, and Ocean Genome Legacy Institute and New England Biolabs in Massachusetts, USA. Within this program, the University of Central America (UCA) is creating the

1 Secretariat of the Convention on Biological Diversity (2010) Global Biodiversity Outlook 3. Montréal: CBD Secretariat. 
country's first biological repository of tissues and genomes, beginning with sampling from protected areas located along the Pacific coast.

The purpose behind the building of the repository is to create a state-of-theart infrastructure to catalogue, store, preserve and understand local biodiversity by creating a permanent archive and database of DNA from as many species as possible while making their genome archive available for research and training. A biorepository of this scope is a novel endeavor in the Central American region, especially in regard to the study of marine species. As it grows, it will be made available for public service. Researchers from the region will have access to the genomic sequences and tissue samples stored in the biorepository through agreements reached with the UCA.

Here we provide an update on the first phase of the program focused on documenting coastal marine biodiversity in the Estero Real and Padre Ramos estuaries, located in Nicaragua's northern Pacific region.

\section{Materials and Methods}

Sample Collecting. The creation of the genomic biorepository began with the collection of fish, crustaceans, bivalves, gastropods and echinoderms in the Pacific North-West of Nicaragua ${ }^{2}$ (Figure 1). Using a boat as a transportation method, samples were collected between September and November of 2011 from 34 sites in Estero Padre Ramos, and from 26 sites in Estero Real. Samples were preserved in ice as a field preservation method. Fish were collected using trammel netting and hand cast circular netting. Crustacean, bivalve and gastropod samples were collected by hand and stored in hermetically sealed containers labeled with each sampling location.

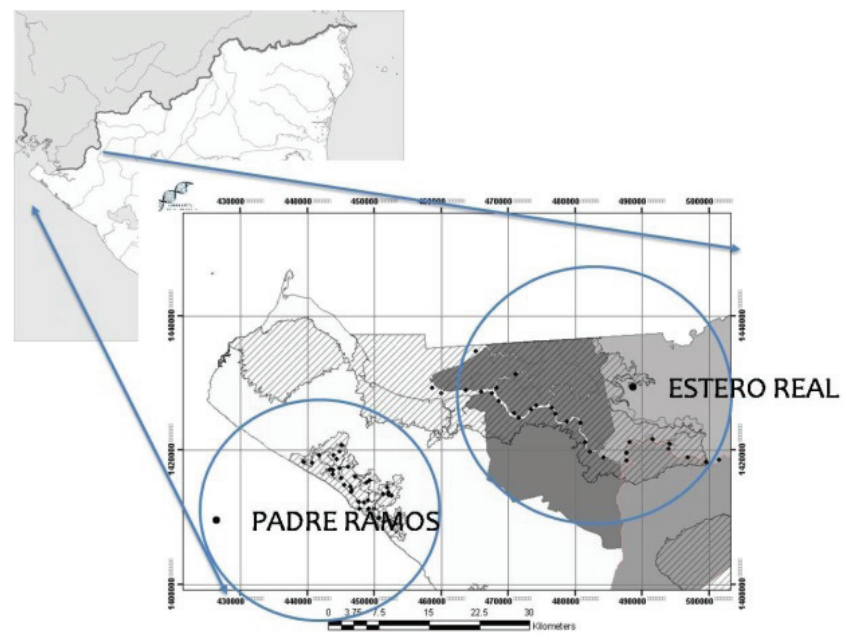

Figure 1. Map of sampling sites in Estero Real and Estero Padre Ramos, Nicaragua. 
Creation of the Biorepository. The Genomic Biorepository of the Molecular Biology Center at the University of Central America in Nicaragua (CBM-UCA) contains voucher specimens, tissue samples and extracted genomic DNA samples. It also includes a database of annotated and validated samples representing a broad cross section of the diversity of life in the sampled areas. Figure 2 shows the work flow of the Genomic Biorepository.

- Voucher specimens: Collection contains digital images of specimens collected along with physical voucher specimens in formaldehyde 9:1. Each specimen was given a code number based on morphological characteristics.

- $\quad$ Tissue samples: Tissue slices are stored in labeled capsules containing 95\% ethanol, which are coded and preserved at $-85^{\circ} \mathrm{C}$.

- Genomic DNA: Genomic DNA is isolated, amplified and stored at $-85^{\circ} \mathrm{C}$. The genome encodes a complete description of an organism's biology, identity, and evolution, as well as clues to its ecological potential and vulnerabilities to disease and stress. Genomic information is essential for conservation of the species.

- Database of collected species: The database contains all information related to collected specimens, including geographic location, specimen code, image code, associated fauna, and other data

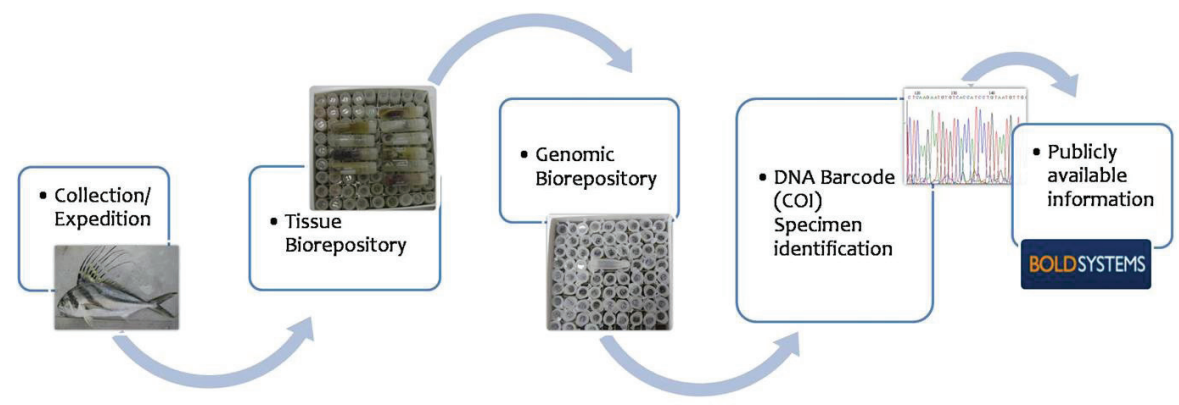

\section{Figure 2. Work flow used to build the genomic biorepository}

Identification of specimens. Morphological Identification was carried out using the FAO Species Identification Guide ${ }^{3}$ and international databases with photographic images including Frenule, FishBase, World Registry of Marine Species, Marine Species Identification Portal, Discover Life Encyclopedia and Ocean Biogeographic Identification System.

DNA barcode identification. DNA extraction was done through anionic exchange, using DNA Biosprint 96 (QIAGEN). For some specimens, alternative extraction methods were used (Organic Extraction Protocol, SDS and Genomic DNA Purification Kit, Promega). The extractions done were quantified in $0.8 \%$ agarose gels. Following DNA extraction of the collected samples, the standard animal

3 Food and Agriculture Organization. (FAO) (1995). Guía FAO para la identificación de especies par los fines de la pesca, pacífico centro oriental, Roma. Vol: 1,2 y 3. 
barcode marker, cytochrome c oxidase subunit 1 (COI), was amplified by PCR .

The PCR reaction mix was carried out using Phusion Master Mix (New England Biolabs) following manufacturer recommendations. Primers used for amplification were FishF1-5' and FishR1-5' for fish, CrustF1 and CrustR1 for crustaceans, and dgLCO2198 and dgHCO1490 for mollusks and bivalves. Once the desired amplicon was obtained, the sample was cleaned with EXO/AP enzymatic cocktail. We used the Sanger sequencing method with terminators marked with fluorescence. The sequencing reactions were carried out with the BigDye Terminator kit version 3.1, following manufacturer instructions, and resolved with an ABI 3130 capillary Genetic Analyzer (Applied Biosystems).

After analyzing their quality, the obtained sequences were compared to sequences published in international databases such as the National Center for Biotechnology Information (NCBI) and the Barcode of Life Database (BOLD Systems). Beginning with homologous sequencing, similarities with our obtained sequences were determined.

Phylogenetic tree of fish species. The information gathered by electropherograms was compared with the taxonomic identification of the specimens. For the appropriate identification of collected species we used a combination of taxonomic and molecular techniques. The DNA barcode sequences obtained from 19 fish species from both Estero Real and Padre Ramos estuaries were used to build a phylogenetic tree. The Neighbor-Joining method (Nei, M. \& Kumar, S., 2000) was used with 1000 Bootstrap repetitions of a total of 500 nucleotides per specimen for 20 sequences, showing Bootstrap values over 50 .

\section{Results and Discussion}

Diversity of specimens in the biorepository. As of February 2012, the biorepository contained more than 3 thousand stored tissue and genomic specimens, comprising 1,049 samples (714 specimens from Estero Padre Ramos and 335 from Estero Real) belonging to 100 species and 54 families, genomic extracts in triplicates for every sample collected and environmental sandy samples representing 60 different sites. Not included in this total are a growing number of DNA barcode sequences that have been generated and published to public databases such as BOLDSYSTEMS (Table 1).

In Estero Real, Crustaceans make up the most representative group, while in Padre Ramos the most representative group consists of Gastropods (Figure 3A and 3B).
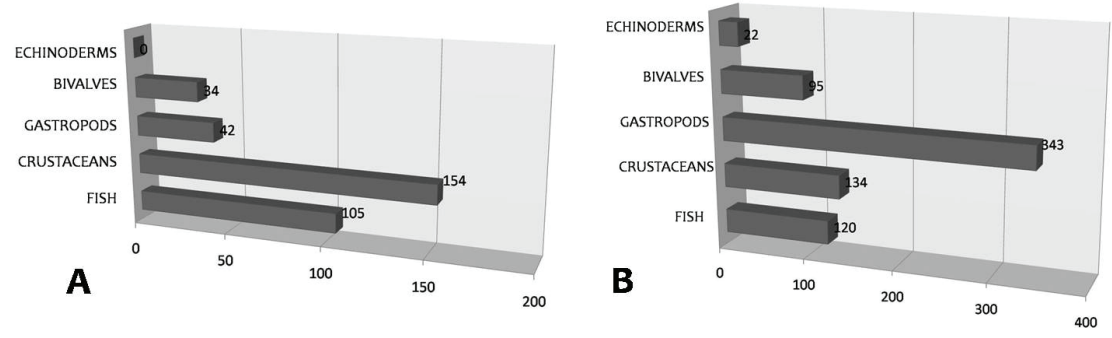

Figure 3. Number of specimens deposited in the biorepository. (A) Estero Real and (B) Padre Ramos. 
Previously unrecorded species for sampled locations. To get an idea of species diversity and to assess changes in species richness and distribution over time, we compared our data (number of species in our collection) to those reported in previous surveys of the same region. The data used for comparisons were taken from studies by the Nicaraguan Ministry of the Environment and Natural Resources (MARENA) and by the Center for Fisheries Research and Aquaculture (CIPA, Nicaragua) in 2001 and 2006. We have found some significant differences with our data. Our Genomic Biorepository for Estero Real and Estero Padre Ramos includes a number of species previously unrecorded for the sampled locations. For Estero Real, we compared our 2011 data with published data from 2001, whereas for Padre Ramos we compared our data with those from 2006 (Figure 4 A and B).

With respect to Estero Real, species previously unrecorded were for Class Osteichthyes: Poecilia sp., Gobionellus sp., Achirus sp., Batrachoides sp., Syacium sp., Gobiomorus sp., Caranx sp., Bairdiella sp., Umbrina sp., Anchoa sp.; Gastropods: Thais kiosquimormis, Cerithideae mazatlantica, Melampus carolianus, Littorina varia, Littorina aspera; and Crustaceans: Uca sp.1-5, Sesarma sp., Pannixa sp., Ballanus sp., Ocypode sp., Goniopsis sp., Clibanarius sp., Palaemon sp., Menipe sp., Aratus sp. and Grapsus sp.

In Estero Padre Ramos we found new records for Osteichthyes: Pseudobalistes sp., Abudefduf sp., Diodon holocanthus., Namatistius pectoralis, Sphyraena sp., Rypticus sp., Diapterus sp., Pomadasys sp., Mugil cephalus, Caranx caballus, Lutjanus argentiventris, Ablennes sp., Tylosurus acus pacificus; and Crustaceans: Menippe sp., Ozius sp., Pinnixa sp., Balanus sp., Leucosia sp., Clibanarius sp., Ocypode sp., Grapsus sp. and Gecarcinus sp.
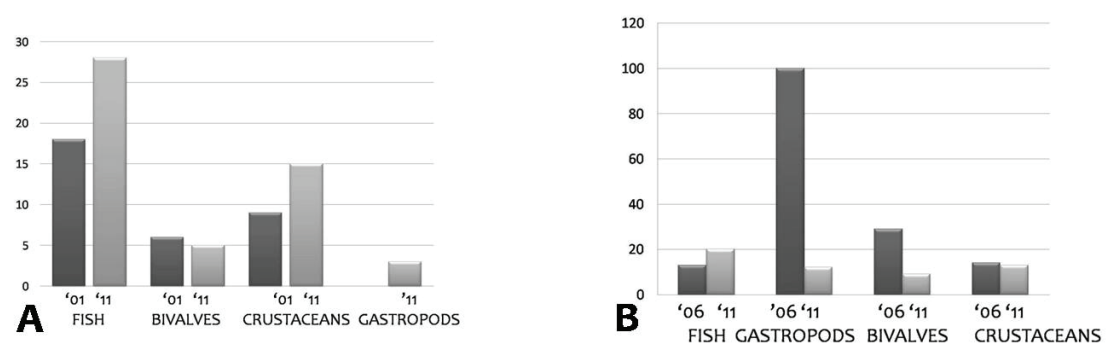

\section{Figure 4. Comparing species diversity in the biorepository (2011) to that from previous records. (A) Estero Real (2001) and (B) Padre Ramos (2006).}

Biodiversity of fish in the biorepository. To date, the Molecular Biology Center (CBM-UCA) has published a total of 23 DNA Barcode sequences of fish species collected for the Genomic Biorepository, which is comprised of COI sequences in [.abi] format with specimen image, scientific name of specimen, specimen collection site, and DNA barcode illustration ${ }^{4}$. COI sequences from 19 different fish species from both Estero Real and Padre Ramos estuaries were used to build a phylogenetic tree, representing the biodiversity and relationship of these fish species (Figure 5). There are certain species, such as Anableps dowei, that may be worth studying in 
depth to determine, for example, their remarkable ability to colonize dissimilar environments.

Collections in natural history museums and other repositories of preserved biological materials provide a resource for understanding biodiversity. Traditionally, these collections have focused on complete physical specimens. Now, however, with great advances in technology in recent decades, we can examine genes, chromosomes, and whole genomes. Genomic information has helped us to redefine species that are closely related, and clarify patterns and proportions of evolutionary diversification among species (Hanner, R., 2007). The explosive growth of molecular databases has enabled us to recognize small sequences of DNA taken from standardized regions of the genome, such as the COI gene. This gene is currently being used as barcode, a short DNA sequence that is unique to a specific organism (Hebert, Cywinska, Ball, $\&$ deWaard, 2003). In animals, COI has been shown to be unique to any given species. Similar sequences have been found for plants, and scientists are actively searching for barcode genes in bacteria, fungi and other microorganisms.

Creating a baseline record for decision making and conservation. Using taxonomic data from biological collections and available publications facilitates the determination of a preliminary biodiversity baseline - a snapshot of the current state of biodiversity. The data summarized in this paper represent a preliminary baseline of species found in the Estero Real and Padre Ramos estuaries, which will be used to produce maps of the potential distribution of highly valued species in that highly valued ecosystem. Samples are now being collected on the Caribbean coast to extend this work to other critical areas of the country and the region. Such a baseline and its supplementary database are important to establish the evidence necessary for stepping up decisive actions to address the current biodiversity crisis as it affects the Central American region.

Furthermore, the CBM-UCA is launching an international initiative to study and preserve local marine biodiversity and ecosystems. In this initiative the key aims are to train, educate and coordinate research on coastal marine biodiversity and water quality in underserved countries of Central America, particularly Honduras, El Salvador and Nicaragua (Huete-Perez, J.A., Roberts, R.J. and Quezada, F., 2012).

The sampling and cataloging of organisms is already resulting in the creation of an open biorepository of marine life (tissues and genomic DNA) found along the Pacific and Caribbean coasts of these countries, providing a baseline for future research. Sequenced samples will reveal fluctuations in species and population counts, as well as adaptations to changing environmental factors such as ocean acidification in the Caribbean and climate change. The direct effect of climate change in the Caribbean was felt in 2005 when an historic hurricane season destroyed nearly half of the Caribbean's coral reefs. World Conservation Union (ICUN) scientists predict that such hurricanes will become more common in the region. According to data presented at the UN COP18 by the Germanwatch Global Climate Risk Index, Honduras, Myanmar and Nicaragua were the most affected by extreme weather events from 1992 to $2011^{5}$.

5 Global Climate Risk Index, 2013. This Index analyses to what extent countries have been affected by the impacts of weather-related loss events (storms, floods, heat waves etc.) Available at http://germanwatch.org/ en/download/7107.pdf 
During field sampling for the CBM-UCA Genomic Biorepository, two workshops were held with community members from the areas of study to disseminate the information gathered. Project outcomes were presented to community members, cooperatives from the area, and shrimp farmers. Working with local communities is a key feature of our project's strategy to foster sharing of knowledge and diverse perspectives among workshop attendees (community) and to identify next steps towards applying the program's findings to improve decisionmaking and management. Together with local authorities we are designing systems that provide legal protection for the target species while allowing economic activities that are controlled and sustainable. The program thereby contributes directly to sustainable community income generating activities and the conservation of genetic diversity.

Implications for environmental policies and management. Constant monitoring of species populations in the estuaries is crucial for generating diversity indexes and comparing them over time to determine the effects of shrimp farming on local aquatic ecosystems. It is also necessary to determine genetic variability within local species to find out if certain marker species in the estuaries are being subjected to drastic changes. We have stressed the need to regulate blast fishing to avoid a massive loss of species from the estuaries.

Community members from both natural reserves studied must be made aware of the value of the natural reserves that surround them and their responsibility for protecting these precious resources, instead of overexploiting them. A current example of overexploitation is that of the bivalve Anadara sp. which is being decimated by residents of Estero Padre Ramos, and as a result, the environment has been left without natural filters of suspended matter, which could result in bacterial growth dangerous to the community. Gastropod and bivalve populations must also be carefully monitored because of their importance in maintaining a well functioning ecosystem within the mangrove swamps.

In Estero Real, the Whiteleg Shrimp, Litopenaeus vanamei, is becoming an invasive species due to a lack of control over shrimp escaping from the farming gates. During sampling, we collected a total of 138 Litopenaeus vanamei, up to $15 \mathrm{~cm}$. The fresh water shrimp Macrobrachium carsinus may be benefiting from the population explosion of Litopenaeus vanamei. Predators of Macrobrachium carcinus could be feeding on Litopenaeus vanamei instead of Macrobrachium carcinus. We collected 120 specimens of Macrobrachium carcinus. This imbalance is placing a burden on the ecosystem and will undoubtedly result in negatively impacting species that do not feed on crustaceans, but having a positive impact on those species that do feed on them. While collecting specimen samples, we also measured physico-chemical parameters in the estuaries (data not shown) in which anoxia is clearly seen in the aquatic ecosystem of Estero Real. This could be due to multiple factors including the overpopulation of Litopenaeus sp. Sedimentation of the Estero Real is also a problem which is contributing to the homogenization of the habitat's biodiversity.

The presence of certain fish, such as Batrachoides sp., Achirus sp. and Syasium sp., collected in exceedingly muddy waters suggests that the Estero Real ecosystem may be undergoing a process of sedimentation in which certain resident fish are adapting to low light and low visibility. The average size of specimens taken has 
been small, although those collected in Estero Padre Ramos are of rather medium size. No fish were trapped using trammel netting in Estero Real, which could mean that conditions are not viable for the entrance of big fish as they consume more oxygen, and it is likely that their gills are damaged at the estuary entrance due to low visibility. Their lack of numbers could also be due to overfishing or to changes in the physico-chemical characteristics of the environment (Williams, S. \& Grosholz, E. (2008).

In Estero Padre Ramos, we found new resident populations only for fish and crustaceans. This estuary has acceptable physico-chemical parameters, and there is not as much pressure on the ecosystem as is seen in Estero Real. Although the ecosystem is well preserved and there isn't much anthropogenic influence upon it, some local residents are concerned about changes in the biological composition of the area. An example of this involves the Güicho, a fish which was a frequent component of local dishes but which is no longer easy to find.

Figura 5. A phylogenetic tree prepared from COI sequences aligned with Clustal X2. Sequences were analyzed as follows: Neighbor-Joining Tree (2000) was used as the clutering method, analysis of nucleotides (transition substitions only) with Bootstrap value of 1000 replications (showing Bootstrap value over 50), statical analysis using MEGA 5.1 software. The code sequences "gi........." are the sequences published in Gene Bank.

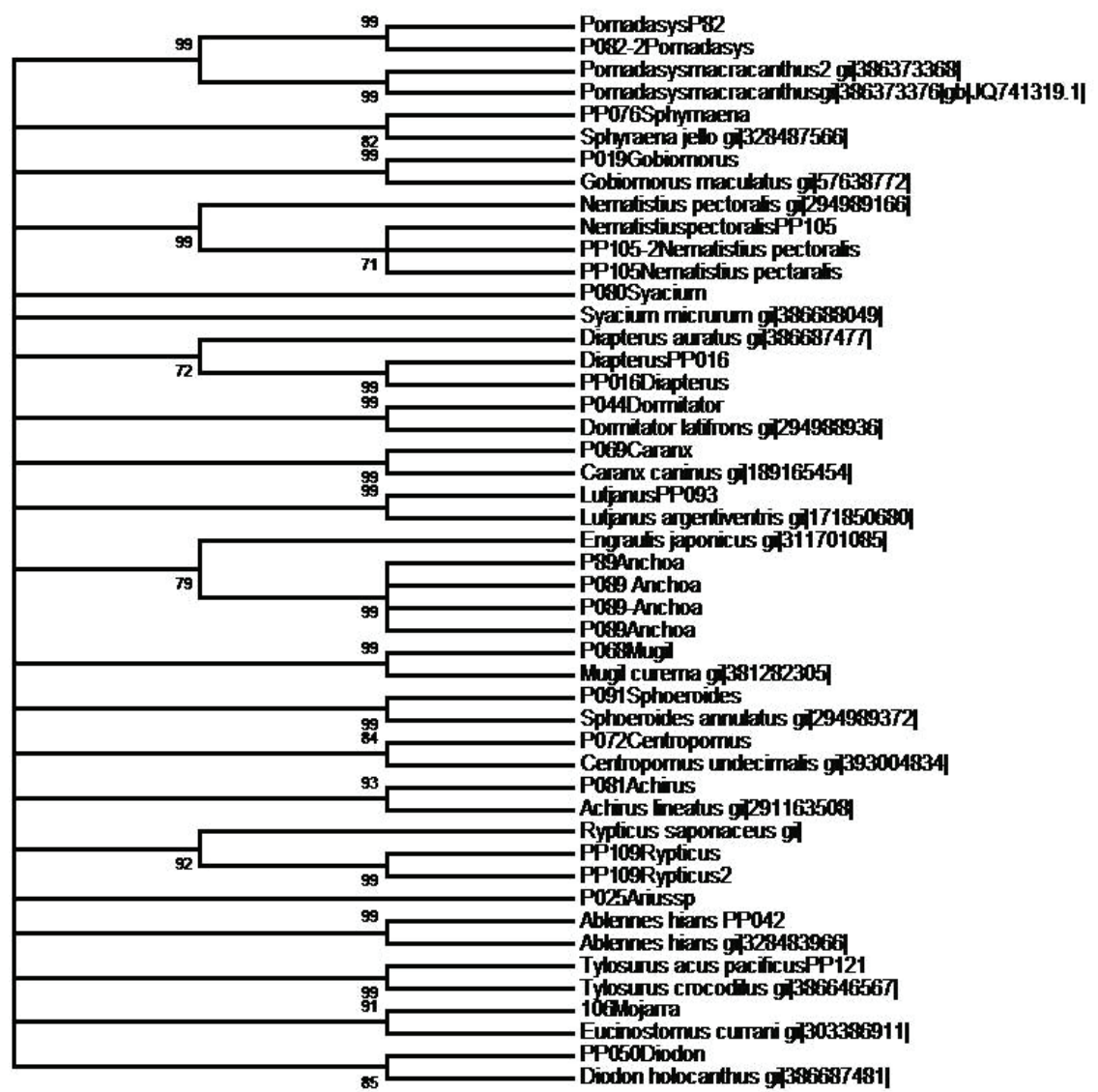


Geographic characteristics of these estuaries should be studied in depth and sampling procedures should be standardized to make true comparisons and to confirm or negate some of the hypotheses mentioned. In fact, we found that sampling and monitoring techniques lack a common standard in the region, and without doubt, coastal marine biodiversity reported to be limited in this region is likely due to low levels of sampling (Miloslavich et al., 2010).

In Nicaragua, biodiversity documentation has focused primarily on commercial species. The most complete records deal with organisms of particular interest to individual researchers studying specific taxonomic branches. Some biodiversity databases have been created through surveys, and are important sources of information on species endemic in certain areas. They are, however, not very useful for evaluating changes in populations and in future populations of organisms with morphological and molecular characterization of the organisms living in a given ecosystem. To study these changes, a baseline account of current populations and conditions must be created against which future studies on population density, range and variation can be compared.

The records contained in the Genomic Biorepository here described lay the foundation for the most complete biodiversity database in Nicaragua and are available to national and international specialists. With this pioneering project of the Center for Molecular Biology, we were able to update the baselines of the reserves in question, and to update national study methods in the field of biodiversity. Field research is underway in the coastal marine environment to provide data on the current state and trends of this special region's biodiversity.

\section{Acknowledgement}

We would like to thank the Research Directorate of the University of Central America (UCA) in Nicaragua for funding this project. In particular we thank Renata Rodrigues and Wendy Bellanger. We would also like to thank Carlos Rivas and his team at the Institute for Training on Environmental Research and Development (CIDEA) at the UCA for having collaborated with sample collections. We are grateful to Dan Distel of the Ocean Genome Legacy (OGL), Jim Ellard and Sir Richard Roberts (New England Biolabs) for their ongoing enthusiastic support.

Table 1. List of species collected for the Genomic Biorepository in Estero Real (ER) and Estero Padre Ramos (PR) 2011.

FISH

FISH

\begin{tabular}{cccccccc}
\hline Family & Genus & Species & Location & Family & Genus & Species & Location \\
\hline Balistidae & Pseudobalistes & N/D & PR & Centropomidae & Centropomus & robalito & ER \\
\hline Pomacentridae & Abudefduf & N/D & PR & & Centropomus & sp & ER \\
\hline Diodontidae & Diodon & holocanthus & PR & Sciaenidae & Cynoscion & albus & ER \\
\hline Nematistiidae & Namatistius & pectoralis & PR & & Bairdiella & armata & ER \\
\hline Sphyraenidae & Sphyraena & N/D & PR & & Umbrina & sp & ER \\
\hline Serranidae & Rypticus & N/D & PR & & Bairdiella & & ER \\
\hline Gerreidae & Diapterus & N/D & & Lutjanidae & Lutjanus & guttatus & PR \\
\hline & Eugerres & N/D & PR,ER & & Lutjanus & argentiventris & ER,PR
\end{tabular}




\begin{tabular}{|c|c|c|c|c|c|c|c|}
\hline & Gerres & $\mathrm{N} / \mathrm{D}$ & & & Lutjanus & $\mathrm{sp} 2$ & PR \\
\hline Anablepidae & Anableps & dowei & ER & $\underline{\text { Tetraodontidae }}$ & Sphoeroides & sp1 & ER \\
\hline Cichlidae & Cichlasoma & $\mathrm{N} / \mathrm{D}$ & ER & & Sphoeroides & $\mathrm{sp} 2$ & ER,PR \\
\hline \multirow[t]{2}{*}{$\overline{\text { Ariidae }}$} & Arius & sp1 & ER & & & & \\
\hline & Arius & sp2 & ER & & & & \\
\hline Poecilidae & Poecilia & $\mathrm{N} / \mathrm{D}$ & ER & & & & \\
\hline Elopidae & Elops & $\mathrm{N} / \mathrm{D}$ & ER & & & & \\
\hline$\underline{\text { Gobiidae }}$ & Gobionellus & $\mathrm{N} / \mathrm{D}$ & ER & & & & \\
\hline Cichlidae & Oreochromis & $\mathrm{N} / \mathrm{D}$ & ER & & & & \\
\hline Achiridae & Achirus & $\mathrm{N} / \mathrm{D}$ & ER & & & & \\
\hline Batrachoididae & Batrachoides & $\mathrm{N} / \mathrm{D}$ & ER & & & & \\
\hline Haemulidae & Pomadasys & $\mathrm{N} / \mathrm{D}$ & ER,PR & & & & \\
\hline Paralichthyidae & Syacium & $\mathrm{N} / \mathrm{D}$ & ER & & & & \\
\hline \multirow[t]{2}{*}{ Belonidae } & Ablennes & $\mathrm{N} / \mathrm{D}$ & PR & & & & \\
\hline & Tylosurus & N/D & PR & & & & \\
\hline Lobotidae & Lobotes & pacificus & ER & & & & \\
\hline Engraulidae & Engraulis & Sp1 & ER & & & & \\
\hline \multirow[t]{2}{*}{$\overline{\text { Mugilidae }}$} & Mugil & $\mathrm{N} / \mathrm{D}$ & ER,PR & & & & \\
\hline & Mugil & N/D & ER,PR & & & & \\
\hline \multirow[t]{2}{*}{ Eleotridae } & Dormitator & latifrons & ER & & & & \\
\hline & Gobiomorus & N/D & ER & & & & \\
\hline \multirow[t]{4}{*}{ Carangidae } & Oligoplites & altus & PR & & & & \\
\hline & Caranx & caninus & ER & & & & \\
\hline & Oligoplites & $\mathrm{sp} 2$ & ER & & & & \\
\hline & Caranx & caballus & PR & & & & \\
\hline Centropomidae & Centropomus & nigriscens & ER & & & & \\
\hline
\end{tabular}

CRUSTACEA

\begin{tabular}{|c|c|c|c|c|c|c|c|}
\hline Family & Genus & Species & Location & Family & Genus & Species & Location \\
\hline Sesarmidae & Aratus & $\mathrm{N} / \mathrm{D}$ & ER,PR & Ocypodidae & Uca & sp3 & ER \\
\hline \multirow{2}{*}{ Menippidae } & Menippe & $\mathrm{N} / \mathrm{D}$ & ER,PR & & Uca & sp4 & PR \\
\hline & Ozius & $\mathrm{N} / \mathrm{D}$ & PR & & Uca & $\mathrm{sp} 5$ & ER,PR \\
\hline Pinnotheridae & Pinnixa & $\mathrm{N} / \mathrm{D}$ & ER,PR & & Ocypode & sp2 & PR \\
\hline Balanidae & Balanus & $\mathrm{N} / \mathrm{D}$ & ER,PR & Grapsidae & Goniopsis & $\mathrm{N} / \mathrm{D}$ & ER,PR \\
\hline$\underline{\text { Leucosiidae }}$ & Leucosia & $\mathrm{N} / \mathrm{D}$ & PR & & Gionopsis & $\mathrm{N} / \mathrm{D}$ & ER,PR \\
\hline \multirow[t]{2}{*}{$\underline{\text { Portunidae }}$} & Callinectes & $\mathrm{N} / \mathrm{D}$ & ER,PR & & Grapsus & $\mathrm{N} / \mathrm{D}$ & ER \\
\hline & Callinectes & $\mathrm{N} / \mathrm{D}$ & ER & Gecarcinidae & Gecarcinus & $\mathrm{N} / \mathrm{D}$ & ER \\
\hline Ucididae & Ucides & $\begin{array}{l}\text { Occiden- } \\
\text { talis }\end{array}$ & ER & & Cardisoma & $\mathrm{N} / \mathrm{D}$ & ER \\
\hline \multirow[t]{2}{*}{$\underline{\text { Palaemonidae }}$} & Palaemon & gracilis & ER & & Gecarcinus & $\mathrm{N} / \mathrm{D}$ & PR \\
\hline & Macrobrachium & tenellum & ER & & Cardisoma & $\mathrm{N} / \mathrm{D}$ & PR \\
\hline
\end{tabular}




\begin{tabular}{cccc} 
Sesarmidae & Sesarma & N/D & ER \\
Penaeidae & Xiphopenaeus & N/D & ER \\
& Litopenaeus & N/D & ER \\
Diogenidae & Clibanarius & N/D & ER \\
& Clibanarius & N/D & ER \\
Ocypodidae & Ocypode & sp1 & PR \\
& Uca & sp1 & ER \\
& Uca & sp2 & ER \\
\hline
\end{tabular}

GASTROPODA

\begin{tabular}{cccc}
\hline Family & Genus & Species & Location \\
Naticidae & Natica & N/D & PR \\
$\underline{\text { Nassariidae }}$ & Nassarium & N/D & PR \\
\hline$\underline{\text { Muricidae }}$ & Thais & Kiosquiformis & ER,PR \\
$\underline{\text { Potamididae }}$ & Cerithidea & Mazatlantica & ER,PR \\
$\underline{\text { Batillariidae }}$ & Rhinocoryne & N/D & PR \\
$\underline{\text { Neritidae }}$ & Nerita & N/D & PR \\
$\underline{\text { Planaxidae }}$ & Planaxis & N/D & PR \\
Melampinae & Melampus & carolianus & ER \\
Littorinidae & Littorina & varia & ER,PR \\
& Littorina & aspera & ER,PR \\
Ovidae & olivella & volatella & PR \\
\hline
\end{tabular}

\begin{tabular}{cccc}
\hline \multicolumn{4}{c}{ BIVALVES } \\
\hline Family & Genus & species & Location \\
Donacidae & Iphigenia & N/D & PR \\
Calyptraeidae & Crepidula & N/D & PR \\
\hline Polymesoda & Polymesoda & N/D & PR \\
Veneridae & Pitar & N/D & PR \\
& Chione & subrugosa & PR \\
Calyptraeidae & crepidula & lessoni & PR \\
Naticidae & natica & chemnitzi & PR \\
corbiculidae & polymesoda & inflata & PR \\
Arcidae & Anadara & tuberculosa & ER,PR \\
& anadara & perlabiata & PR \\
& Larkinia & grandis & ER,PR \\
& Anadara & similis & ER,PR \\
Ostreidae & Ostrea & iridiscens & ER
\end{tabular}

\begin{tabular}{cccc}
\multicolumn{4}{c}{ POLICHAETA \& ECHINODERMS } \\
Class & Genus & Species & Location \\
Echinoidea & Mellita & $\mathrm{sp}$ & $\mathrm{PR}$ \\
Ophiuroidea & Ophioderma & $\mathrm{sp}$ & $\mathrm{PR}$ \\
\hline Polichaeta & $\mathrm{N} / \mathrm{D}$ & $\mathrm{N} / \mathrm{D}$ & $\mathrm{PR}$ \\
\hline
\end{tabular}




\section{References}

Centro de Investigaciones Pesqueras y Acuícolas. (CIPA) (2007). Diagnostico de la actividad Pesquera artesanal en el Estero Real. Managua. Retrieved from www. sinia.net.ni/publicaciones/finish/199/1805/0.html in December 3, 2012.

Hanner, R. \& Gregory R. (2007). Genomic Diversity Research and the Role of Biorepositories. Cell Preservation Technology. Vol: 5, No. 2. Retrieved from http://www.genomesize.com/rgregory/reprints/Hanner_Gregory_CPT.pdf in December 3, 2012.

Hebert, P. D., Cywinska, A., Ball, S. L., \& deWaard, J. R. (2003). Biological identifications through DNA barcodes. Proc Biol Sci, 270(1512), 313-321. doi: $10.1098 / \mathrm{rspb} .2002 .2218$

Huete Pérez., Roberts R.J. \& Quezada, F. (2012) Marine genome resource sustainability in Central America. Electronic journal of biotechnology, Vol: 15 no5. Retrieved from http://www.ejbiotechnology.info/index.php/ejbiotechnology/article/ viewFile/v15n5-14/1524 in December 2012.

MARENA. (2003). Plan de manejo Padre Ramos. Nicaragua. Retrieved from www.sinia. net.ni in December 3, 2012.

Miloslavich, P., Diaz, J. M., Klein, E., Alvarado, J. J., Diaz, C., Gobin, J., . . . Ortiz, M. (2010). Marine biodiversity in the Caribbean: regional estimates and distribution patterns. PLoS One, 5(8), e11916. doi: 10.1371/journal. pone.0011916

Nei, M. \& Kumar, S. (2000). Molecular Evolution and Phylogenetics. (1 ${ }^{\text {st }}$ ed.). New York: Oxford University Press.

Williams, S. \& Grosholz, E. (2008). The Invasive Species Challenge in Estuarine and Coastal Environments: Marrying Management and Science. Springer-Verlag.Vol: 31 Issue 1, (3-20). Retrieved from www.vliz.be/imisdocs/publications/133708. pdf in December 2012.

Worm, B., Barbier, E. B., Beaumont, N., Duffy, J. E., Folke, C., Halpern, B. S., . . Watson, R. (2006). Impacts of biodiversity loss on ocean ecosystem services. Science, 314(5800), 787-790. doi: 314/5800/787 [pii] 10.1126/science.1132294 